The Essentials of Volumetric Analysis

By John Lambert, in conjunction with A. Holderness, and Dr. F. Sherwood Taylor. Pp. vii +92. (London: William Heinemann, Ltd., 1938.) 2s. $6 d$.

THIS book provides a suitable course in volumetric analysis for the higher school certificate examinations. Thus an account is given of the preparation and use of standard solutions of acids, alkalis, potassium permanganate and dichromate, iodine, thiosulphate, and silver nitrate in neutral and acid solution. A concise and clear explanation is also given of the theory of indicators, including adsorption indicators. A useful feature of the book, especially from the point of view of scholarship candidates, is the list of practical problems at the ends of the chapters. Atomic weights, tables of logarithms and an index are given at the end of the book.

A. C. C.

Ergebnisse der Vitamin- und Hormonforschung Herausgegeben von E. Mellanby und L. Ruzicka. Band 2. Pp. xv +520. (Leipzig: Akademische Verlagsgesellschaft m.b.H., 1939.) 34 gold marks.

THIS survey of current knowledge in selected fields of hormone and vitamin research, of which the first volume was reviewed in Nature, 143,659 (1939), maintains the cosmopolitan aspect to which we then directed attention. Four articles are in English, all from England : four are in German, one from the United States, one from Switzerland and two from Germany: three are in French, two from France and one from the Argentino.

The authoritative nature of the various contribu. tions leaps to the eye. Profs. Haworth and Hirst write on the chemistry of ascorbic acid and its analogues : Prof. Bertrand contributes an essay on the physiological significance of manganese and other 'trace' elements : Dr. Hans Brockmann discusses the chemistry of the antirachitic vitamins, and Prof. Rominger their physiology and pathology. Prof. J. W. Cook describes the chemical and biological properties of the carcinogenic substances, while an analysis by Prof. Lacassagne of the connexion between cancer and the sex hormones is reassuring in its conclusions. Prof: Houssay and Dr. Deulofeu have somo forty-five pages on the chemistry and secretion of insulin. Prof. Karrer appropriately reviews the chemistry of the flavins. Articles by Dr. Hargen-Smit on the plant growth-hormones and by Prof. Korenchevsky on the bisexual (and other) effects of pure male hormones on females make up the eleven sections of the book.

Thus it will bo seen that, like its predecessor, this volume ranges from chemistry to clinical medicine, with adequate attention to the intermediate co. sciences of bio-chemistry, physiology, therapeutics and pathology. A change of editorship is to be observed in the replacement of Prof. W. Stepp by Sir Edward Mellanby; one can only speculate as to where and when subsequent volumes will be published and hope that these "Ergebnisse" will not have to be included among the war victims.

A. I. BACHARACH.
ENGINEERING

Les gisements de pétrole

Géologie, statistique, économie. Par Prof. Georges Macovei. Pp. vii +502. (Paris: Masson et Cie., 1938.) 120 francs.

M GEORGES MLACOVEI. is well qualified to N1. write a text-book on petroleum since he brings to the task twenty years of experience as a lecturer at the Polytechnic School in Bucharest and thirty years of practical experience of the Carpathian deposits. He has not hesitated to consult the works of already established authorities on the subject in England, France, Germany, the United States and elsewhere, but in addition has embraced many of the precepts of his fellow countrymen, in particular those of M. Louis Mrazec, of whom he is an admiring disciple. Those who are looking for originality may therefore be disappointed, certainly in regard to text figures, only about twenty of which are entirely now out of a total of two hundred and twenty-two.

The first part of the book follows conventional procedure in petroleum text-books, and the accepted principles of petroleum origin, constitution, production, etc., are unfolded along familiar lines. The author relioves monotonous sequences of facts wherever possible by reference to practical examples he has encountered in the field; but, boing most familiar with the Rumanian oilfields, he tends perhaps to over-emphasize their importance in relation to oil deposits in other parts of the world.

The second half of the book is devoted to a description of the known deposits of petroleum through. out the world. No attempt is of courss made to give complete details of all deposits, but indications aro in each case given of oxtent, yield and potential reserves.

Few writers of text-books on petroloum can with. stand the temptation to estimate world resources of this product. Mr. Macovei succumbs in the last chapter and quotes some astonishing figures. From statistics gleaned from a variety of sources ho estimates that world reserves at the beginning of 1938 were 5,173 million tons. He then proceeds to calculate on $\&$ basis of 1937 withdrawals that petroleum will be exhausted in Mexico in five years, in the United States in twelve years and in Rumania in thirteen. Even Iraq, the supplies of which are expected to outlast those of the rest of the world, will have exhausted her reserves in less than a hundred years according to this author's approximations.

\section{Petroleum Production Engineering}

Oil Field Exploitation. By Prof. Lester Charles Uren. Second edition. Pp. ix +756 . (Now York and London: HcGraw-Hill Book Co., Inc., 1939.) 36.8 .

THE fact that Prof. Uren has had to expand the first edition of this work, which he wrote fifteen years ago, into two volumes and approximately twice as many pages is yet another indication of the steadily accumulating mass of technical knowledge now available to the petroleum industry. The work 